\title{
Tumor Necrosis Factor- $\alpha$ Gene and Protein Expression in Adult Feline Myocardium after Endotoxin Administration
}

\author{
Samir Kapadia, Joseph Lee, Guillermo Torre-Amione, Holly H. Birdsall, Tony S. Ma, and Douglas L. Mann \\ Cardiology Section of the Department of Medicine, and the Departments of Otorhinolaryngology and Microbiology and Immunology, \\ Veterans Administration Medical Center; and Baylor College of Medicine, Houston, Texas 77030
}

\begin{abstract}
TNF $\alpha$ mRNA and protein biosynthesis were examined in the adult feline heart after stimulation with endotoxin. When freshly isolated hearts were stimulated with endotoxin in vitro, de novo TNF $\alpha$ mRNA expression occurred within 30 min, and TNF $\alpha$ protein production was detected within $60-$ 75 min; however, TNF $\alpha$ mRNA and protein production were not detected in diluent-treated hearts. Immunohistochemical studies localized TNF $\alpha$ to endothelial cells, smooth muscle cells, and cardiac myocytes in the endotoxin-treated hearts, whereas TNF $\alpha$ immunostaining was absent in the diluent-treated hearts. To determine whether the cardiac myocyte was a source for TNF $\alpha$ production, two studies were performed. First, in situ hybridization studies, using highly specific biotinylated probes, demonstrated TNFa mRNA in cardiac myocytes from endotoxin-stimulated hearts; in contrast, TNF $\alpha$ mRNA was not expressed in myocytes from diluent-treated hearts. Second, TNF $\alpha$ protein production was observed when cultured cardiac myocytes were stimulated with endotoxin, whereas TNF $\alpha$ protein production was not detected in the diluent-treated cells. The functional significance of the intramyocardial production of TNF $\alpha$ was determined by examining cell motion in isolated cardiac myocytes treated with superfusates from endotoxinand diluent-stimulated hearts. These studies showed that cell motion was depressed in myocytes treated with superfusates from the endotoxin-treated hearts, but was normal with the superfusates from the diluent-treated hearts; moreover, the negative inotropic effects of the superfusates from the endotoxin-treated hearts could be abrogated completely by pretreatment with an anti-TNF $\alpha$ antibody. Finally, endotoxin stimulation was also shown to result in the intramyocardial production of TNF $\alpha$ mRNA and protein in vivo. Thus, this study shows for the first time that the adult mammalian myocardium synthesizes biologically active TNFa. (J. Clin. Invest. 1995. 96:1042-1052.) Key words: TNFa • endotoxin - gene expression - myocyte
\end{abstract}

\section{Introduction}

The deleterious effects of bacterial endotoxin in the mammalian host have been recognized for at least $100 \mathrm{yr}$ (1). This statement

Address correspondence to Douglas L. Mann, M.D., Cardiology Research (151C), Room 234, Building 110, VA Medical Center, 2002 Holcombe Blvd., Houston, TX 77030. Phone: 713-794-7949; FAX: 713794-7770.

Received for publication 23 November 1994 and accepted in revised form 6 April 1995.

The Journal of Clinical Investigation, Inc.

Volume 96, August 1995, 1042-1052 notwithstanding, our understanding of the complex sequence of events that lead to the development of endotoxin-mediated septic shock is still evolving. Indeed, relatively recent studies have identified a potentially important role for circulating myocardial depressant factors such as TNF $\alpha$ in the pathogenesis of endotoxin-mediated septic shock (2-11). While the exact nature of the cell types involved in the endotoxin-mediated release of TNF $\alpha$ has never been established conclusively, it has been traditionally held that the activated monocyte/macrophage is the cell type that is primarily responsible (12). However, several considerations suggest that the release of TNF $\alpha$ by macrophages/monocytes does not satisfactorily explain the development of myocardial depression during septic shock. That is, while the negative inotropic effects of TNF $\alpha$ are concentration dependent $(3,13)$, immunologically detectable levels of TNF $\alpha$ in the circulation do not correlate with the degree of hemodynamic compromise during sepsis $(14,15)$. Further, although TNF $\alpha$ produces negative inotropic effects in the heart within minutes $(3,13)$, the development of endotoxin-induced myocardial depression generally lags several hours behind the temporal appearance of TNF $\alpha$ in the serum and occurs in human subjects at a time when TNF $\alpha$ is no longer immunologically detectable in the serum $(7,16,17)$.

Important to the above discussion is the recent observation that endotoxin-induced biosynthesis of TNF $\alpha$ mRNA and protein is not strictly confined to peripheral mononuclear cells but may also occur within a number of different "tissue compartments" (18-23). Indeed, a recent experimental study has shown that endotoxin stimulation leads to de novo expression of TNF $\alpha$ mRNA in the heart (20). This latter observation raises the interesting possibility that the myocardial depression that occurs in sepsis may develop directly in response to the compartmentalized production of TNF $\alpha$ in the heart, as opposed to the systemic production of TNF $\alpha$ by circulating mononuclear cells. Unfortunately, the aforementioned experimental study (20) did not address the important issue of whether TNF $\alpha$ protein was also produced within the myocardium. Accordingly, the purpose of this study was to systematically examine the biosynthetic and functional effects of endotoxin stimulation in the adult heart. The results of this study constitute the initial demonstration that the adult mammalian myocardium elaborates biologically active TNF $\alpha$, both in vitro and in vivo. Moreover, this study shows that the adult cardiac myocyte itself may be an important source of TNF $\alpha$ production after stimulation with endotoxin.

\section{Methods}

Myocardial TNF $\alpha$ production in vitro

Myocardial TNF $\alpha$ production was assessed in vitro using a modified Langendorff perfusion apparatus $(24,25)$. Briefly, adult cats weighing $3.4 \pm 0.2 \mathrm{~kg}$, and of random sex, were anesthetized with ketamine hydro- 
chloride ( $50 \mathrm{mg} / \mathrm{kg}$ intramuscular) and acepromazine maleate $(5 \mathrm{mg} /$ $\mathrm{kg}$ intramuscular). Before excising the heart, $20 \mathrm{~cm}^{3}$ of blood was gently withdrawn from the femoral artery and allowed to clot in a polystyrene tube; the serum was rapidly separated from the cells by centrifugation at $1,500 \mathrm{~g}$ for $10 \mathrm{~min}$. The serum was then filtered with $0.22-\mu \mathrm{m}$ filter to ensure sterility as well as to remove any contaminating cell types. Once the serum was obtained, the hearts were excised rapidly, rinsed thoroughly in chilled $\left(4^{\circ} \mathrm{C}\right) \mathrm{Krebs}$-Henseleit buffer (KHB), suspended on a cannula, and then perfused at a constant pressure of $80 \mathrm{mmHg}$ using a roller pump. The initial coronary superfusate consisted of a nonrecirculating $\mathrm{KHB}$ solution of the following composition (mM): $\mathrm{NaCl} 130.0, \mathrm{KCl} 4.8, \mathrm{MgSO}_{4} 1.2, \mathrm{NaH}_{2} \mathrm{PO}_{4} 1.2, \mathrm{CaCl}_{2} 0.5, \mathrm{NaHCO}_{3}$ 4.0, glucose 12.5, Hepes 10.0 ( $\mathrm{pH} 7.4$ ), that was oxygenated with $100 \%$ $\mathrm{O}_{2}$ and maintained at $37^{\circ} \mathrm{C}$ by a water bath. The heart was initially perfused for $\mathbf{1 0} \mathrm{min}$ with KHB buffer in a nonrecirculating fashion to remove any blood products; next the superfusate was changed to a recirculating KHB buffer (total volume $300 \mathrm{ml}$ ) containing $5 \%$ autologous feline serum (26) supplemented either with endotoxin (10 or 125 $\mu \mathrm{g} / \mathrm{ml}$ ) or diluent (KHB buffer).

Starting immediately after switching to the recirculating KHB buffer (time 0 ) and for every $15 \mathrm{~min}$ thereafter for a total of $180 \mathrm{~min}$, a 5 -ml sample of the recirculating KHB buffer was collected to determine TNF $\alpha$ bioactivity, as assessed by L929 cytotoxicity assay.

\section{Myocardial TNFa gene expression in vitro}

To study myocardial TNF $\alpha$ gene expression, perfused hearts were stimulated as described previously, either with diluent or a single concentration of endotoxin $(125 \mu \mathrm{g} / \mathrm{ml})$. To determine the time course of TNF $\alpha$ gene expression after diluent or endotoxin stimulation, starting at time 0 and for every $30 \mathrm{~min}$ thereafter for a total of $90 \mathrm{~min}$, a 1-2-gram sample of myocardium was excised from the suspended heart (carefully sparing the large epicardial vessels). The sample was then frozen rapidly in liquid nitrogen and stored at $-70^{\circ} \mathrm{C}$. To study the kinetics of TNF $\alpha$ gene expression after removal of endotoxin stimulation, the hearts were first perfused for $90 \mathrm{~min}$ with a KHB buffer containing $125 \mu \mathrm{g} / \mathrm{ml}$ endotoxin. After this, the superfusate was switched to a solution consisting of KHB buffer alone, and the hearts were perfused for an additional $120 \mathrm{~min}$ (total perfusion time $210 \mathrm{~min}$ ). A 1-2-gram sample of myocardium was excised from the suspended heart at $90,150,180$, and $210 \mathrm{~min}$, frozen rapidly in liquid nitrogen, and stored at $-70^{\circ} \mathrm{C}$. The positive controls for these experiments consisted of HL-60 cells stimulated for $180 \mathrm{~min}$ with endotoxin $(125 \mu \mathrm{g} / \mathrm{ml})$.

Total RNA was extracted from the myocardial samples and the HL-60 cells by the guanidinium thiocyanate method (27). Total RNA was denatured at $65^{\circ} \mathrm{C}$ for $10 \mathrm{~min}$, size fractionated on a $1 \%$ agarose gel containing $2.2 \mathrm{M}$ formaldehyde (10 $\mu \mathrm{g} /$ lane), transferred onto a nylon membrane (GeneScreen; Dupont-NEN, Boston, MA), and hybridized sequentially to random primed cDNA probes (27). The following probes were used for Northern blot analysis: a 0.6-kb HindIII/HindIII fragment of the human TNF $\alpha$ (American Tissue Culture Collection, Rockville, MD) and a 0.5-kb Xba/HindIII fragment of human glyceraldehyde-3-phosphate dehydrogenase (GAPDH), which was used as an internal control. In preliminary control experiments we confirmed that the human TNF $\alpha$ cDNA probe crossreacted with feline TNF $\alpha$ mRNA by hybridizing the cDNA probe to mRNA isolated from endotoxinstimulated $(10 \mu \mathrm{g} / \mathrm{ml} \times 180 \mathrm{~min})$ feline and human mononuclear cells. The membranes were washed one time with SSC and 0.1\% SDS at $55^{\circ} \mathrm{C}$ for $30 \mathrm{~min}$, air dried, and exposed to Kodak X-Omat A film (Eastman Kodak, Rochester, NY) at $-70^{\circ} \mathrm{C}$.

\section{Immunolocalization of myocardial TNF $\alpha$}

To visualize the presence and anatomic localization of TNF $\alpha$ within the myocardium, immunohistochemical studies were performed. Freshly excised hearts were stimulated with diluent or endotoxin $(125 \mu \mathrm{g} / \mathrm{ml})$ for 180 minutes and fixed in $10 \%$ neutral buffered formalin (Z-fix; Anatech, Ltd., Battle Creek, MI) at room temperature for 18-24 h. The tissue was then dehydrated, embedded in paraffin, and sectioned (0.5$\mu \mathrm{M}$ sections) in a standard manner. Immunohistochemistry was per- formed using a computer-driven CODE-ON system (Cambridge Instruments, Nubloch, Germany). All reagents were prepared with a diluent consisting of PBS supplemented with $0.2 \%$ Tween 20 and $0.5 \%$ BSA. To minimize background staining, all sections were first blocked with normal goat serum for $20 \mathrm{~min}$ at room temperature. Next, the slides were incubated with two concentrations $(1: 500$ or 1:1,000) of a primary antibody directed against human TNF $\alpha$ (Genzyme Corp., Cambridge, MA); control slides were stained with secondary antibody alone (1/ 1,000 dilution). Sections were allowed to incubate in a humidified chamber overnight at room temperature. The slides were then rinsed in PBS and incubated for $\mathbf{4 5} \mathrm{min}$ at room temperature with a biotin-conjugated goat anti-rabbit secondary antibody (diluted $1 / 1,000$ ). After blocking of the endogenous peroxidase activity with methanol and hydrogen peroxide, the slides were incubated with an avidin-biotin complex using a peroxidase reporter (Vectastain ABC Kit; Vector Laboratories, Burlingame, CA). Diaminobenzidine was used as the chromogen to visualize the presence and distribution of TNF $\alpha$. Sections were then rinsed in PBS, counterstained in hematoxylin, dehydrated, cleared, and mounted using a synthetic mounting medium.

\section{Cellular source for myocardial TNF $\alpha$ production in vitro}

Previous studies have shown that a variety of cell types in the heart, including fibroblasts, smooth muscle cells, and endothelial cells, elaborate $\operatorname{TNF} \alpha(23,28,29)$. To determine whether the cardiac myocyte might also elaborate TNF $\alpha$, three separate experiments were performed.

First, to study the relative production of TNF $\alpha$ mRNA and protein by myocyte and nonmyocyte cell types in the heart, freshly isolated cat hearts were stimulated with endotoxin $(125 \mu \mathrm{g} / \mathrm{ml})$ for $120 \mathrm{~min}$, as described earlier. The hearts were then enzymatically digested using techniques standard in this laboratory $(24,30)$. After enzymatic digestion of the heart, the cells were rinsed with $\mathrm{KHB}$ and gently centrifuged $(200 \mathrm{~g})$ to separate the myocyte from nonmyocyte cell types. The resultant cell pellet, which contains $>95 \%$ cardiac myocytes, and the cell supernatant, which contains $>95 \%$ nonmyocyte cell types, were then split into two portions and analyzed for TNF $\alpha$ mRNA and protein production. Total RNA was extracted and prepared for Northern analysis as described earlier, using random primed cDNA probes for TNF $\alpha$ and GAPDH. Cytosolic TNF $\alpha$ protein was prepared using a modification of the method of Pizarro et al. (31). Briefly, the cell pellet and supernatant were each subjected to two rapid freeze-thaw cycles, by rapidly immersing the cells in liquid nitrogen and warming the cells in a $37^{\circ} \mathrm{C}$ water bath. The cells were then suspended in PBS and sonicated for 60 $\mathrm{s}$. The lysed cells were then spun down at $5,000 \mathrm{~g}$ to remove particulate cell debris, and the resultant supernatants (cytosolic fraction) from the myocytes and nonmyocytes were tested for TNF $\alpha$ cytotoxicity, using an L929 bioassay as described later. In previous studies we have shown that all of the immunodetectable TNF $\alpha$ in myocardium (human) resides in the cytosolic fraction of myocardial homogenates (32). The amount of TNF $\alpha$ per sample was normalized by the total amount of cytosolic protein. Protein determinations were performed using a commercially available assay (BCA; Pierce, Rockford, IL), using BSA as a standard.

Second, to determine the cellular source(s) of TNF $\alpha$ mRNA production, we performed in situ hybridization studies in diluent- and endotoxin-stimulated hearts. In situ hybridization was performed using custom-synthesized biotinylated oligonucleotide probes (33). A specific antisense oligonucleotide probe was designed based on a segment contained in the coding region of the TNF $\alpha$ gene that was unique to the cat and has not been reported in other vertebrate sequences recorded in GenBank (Intelligenetics, Inc., Mountainview, CA). The antisense oligonucleotide was derived from bases 825-847 of the coding region of TNF $\alpha$, whose sequence was 5' CGGGGTTTGCTACTACATGGGC $3^{\prime}$. To check for the specificity of the hybridization signal, a biotinlabeled sense probe (sequence 5' GCCCATGTAGTAGCAAACCCCG $\left.3^{\prime}\right)$ corresponding to the antisense probe was substituted. Further, to confirm the integrity of the mRNA in each sample, a biotinylated $d(T)_{24}$ single-stranded oligonucleotide was used in all diluent- and endotoxintreated myocardial samples (33). All oligonucleotide probes were hy- 
perbiotinylated at the $3^{\prime}$ end (i.e., three biotin groups attached at the $3^{\prime}$ end) and were synthesized commercially (DNAgency, Ashton, PA).

In situ hybridization was performed exactly according to the method of Bucana et al. (33). Briefly, frozen tissue from diluent and endotoxin hearts were embedded in OCT compound (Miles Laboratories, Elkhart, IN), cut into 5.0- $\mu \mathrm{m}$ sections, and placed on positively charged glass microscope slides (ProbeOn ${ }^{\text {TM }}$ Plus; Fisher Scientific, Pittsburgh, PA). The tissue sections were allowed to come to room temperature, fixed for $20 \mathrm{~min}$ in $4 \%$ paraformaldehyde, and then mounted on a Microprobe ${ }^{\mathrm{TM}}$ (Fisher Scientific) slide holder. Tissue sections were treated with $1 \%$ Triton X-100 in diethyl pyrocarbonate (DEPC) -treated distilled water for $5 \mathrm{~min}$, followed by protein denaturation with $0.2 \mathrm{~N} \mathrm{HCl}$ in DEPC water at $99^{\circ} \mathrm{C}$ for $3 \mathrm{~min}$. In situ hybridization was performed using a probe cocktail consisting of 1:50,000 dilution of random sequence oligomers ( 9 bases long), which were added to aid nucleic acid denaturation (34), and a 1:500 or 1:1,000 dilution of the antisense, sense, or poly $\mathrm{d}(\mathrm{T})$ oligonucleotide probes. First, the probe cocktail was heated for $3 \mathrm{~min}$ at $99^{\circ} \mathrm{C}$ to denature the oligonucleotides. Hybridization of the probes to the tissue samples was performed at $45^{\circ} \mathrm{C}$ for $45 \mathrm{~min}$ and the slides washed for 3 min with $2 \times \mathrm{SSC}$ three times at $45^{\circ} \mathrm{C}$. The hybridized biotinylated probes were localized colorimetrically by incubating the slides with avidin-conjugated alkaline phosphatase, followed by napthol AS-MX phosphate/Fast Red TR chromagen solution (Biomeda Corp., Foster City, CA). The slides were then washed with distilled water containing $0.1 \%$ Brij 35 (Biomeda Corp.), counterstained with hematoxylin for $15 \mathrm{~s}$, and mounted with synthetic mounting medium.

Third, to determine whether endotoxin stimulation would be a sufficient stimulus for TNF $\alpha$ production in cultured adult cardiac myocytes, we treated freshly isolated adult feline cardiac myocytes with diluent or endotoxin. Briefly, cardiac myocytes were isolated from normal cat hearts using standard enzymatic and cell culture techniques $(24,30)$. We have shown previously that fibroblast contamination is minimal $(<2 \%)$, using the cell culture methods described herein $(24)$. The freshly isolated myocytes were suspended in M199 culture medium at a final concentration of $5 \times 10^{4}$ cells $/ \mathrm{ml}$ and allowed to equilibrate for $1 \mathrm{~h}$. The myocyte cultures were stimulated for $4 \mathrm{~h}$ either with diluent (M 199) or with endotoxin ( $10 \mu \mathrm{g} / \mathrm{ml}$ ). The cells were then centrifuged at $1,500 \mathrm{~g}$ for $10 \mathrm{~min}$ and the cell pellets frozen immediately in liquid nitrogen. The cytosolic portions of the diluent- and endotoxin-stimulated cells were prepared exactly as described earlier (31). The amount of TNF $\alpha$ per myocyte culture was normalized by the total amount of cytosolic protein per culture; protein determinations were performed using a commercially available assay (BCA; Pierce), using BSA as a standard.

Three control studies were performed to determine the extent to which contaminating monocytes may have contributed to TNF $\alpha$ production in the myocyte cultures. First, we used flow cytometry to determine the number of monocytes present in the freshly isolated myocyte cultures. Briefly, myocyte cultures were prepared as described earlier and then immunostained for $30 \mathrm{~min}$ at $4^{\circ} \mathrm{C}$ with saturating quantities of phycoerythrin-conjugated murine anti-CD14 (Dako Corp., Carpinteria, $\mathrm{CA}$ ) or phycoerythrin-conjugated murine $\mathrm{IgG}_{1}$ isotype control sera. The cultures were then washed with cold Dulbecco's phosphate-buffered saline and fixed in $1 \%$ paraformaldehyde. Flow cytometry (Epics Profile I; Coulter Cytometry, Hialeah, FL) was performed using an argon beam laser tuned to $488 \mathrm{~nm}$, with three fluorescence channels. Fluorescence data from isotype controls were subtracted from data obtained with the anti-CD14 antibodies. The percentage of contaminating monocytes was also determined in a different manner, by incubating the myocyte cultures with fluorescent beads (Molecular Probes, Eugene, OR) and then using microspectrofluorometry to determine the number of cells phagocytosing the fluorescent beads. In preliminary control experiments, we confirmed that the cardiac myocytes did not phagocytose the fluorescent beads. Second, we determined the amount of TNF $\alpha$ production that was theoretically possible based on the predicted number of contaminating monocytes in the myocyte cultures. For these studies, feline peripheral blood mononuclear leukocytes were harvested using gradient centrifugation (Ficoll,) and lymphocyte separation medium (Organon Teknika,
Durham, NC), enumerated using a hemocytometer, and then cultured in RPMI medium containing $10 \%$ FCS. The fraction of monocytes in the peripheral blood mononuclear cell cultures was calculated from the percentage of mononuclear cells phagocytosing iron beads, which was also the same as the percentage of mononuclear cells that stained positively for CD14. The number of peripheral blood mononuclear cells per culture dish was adjusted such that the absolute number of monocytes in culture bracketed the absolute number of monocytes present in the myocyte cultures. The peripheral blood mononuclear cells were stimulated with endotoxin exactly as described earlier for the cardiac myocytes, and the amount of mononuclear cell-derived TNF $\alpha(\mathrm{U} / \mathrm{ml})$ was measured by bioassay. Finally, we examined TNF $\alpha$ production in monocyte-depleted myocyte cultures in the presence and absence of endotoxin stimulation. For these studies, monocyte depletion was achieved by incubating the myocyte cultures with iron beads ( Technicon Instrument Co., Tarrytown, NY) for $1 \mathrm{~h}$ at $37^{\circ} \mathrm{C}$ in RPMI medium containing $10 \%$ autologous cat serum. The monocytes, which will phagocytize the iron beads, were then selectively depleted from the myocyte cultures using a magnet (Dynal, Great Neck, NY). In preliminary control experiments we determined that, under the culture conditions used herein, viable cardiac myocytes did not ingest iron beads. The amount of TNF $\alpha$ in the monocyte-depleted myocyte cultures was determined as described earlier.

\section{Myocardial TNF $\alpha$ mRNA and protein biosynthesis in vivo}

To determine whether endotoxin challenge would stimulate TNF $\alpha$ mRNA and protein production in vivo, adult cats of random sex, weighing $3.4 \pm 0.2 \mathrm{~kg}$, were anesthetized, instrumented with a 20-gauge cannula, and treated with either diluent or endotoxin. Endotoxin was administered as an initial $100 \mu \mathrm{g} / \mathrm{kg}$ bolus intravenously over $5 \mathrm{~min}$ (35), followed by five subsequent $100 \mu \mathrm{g} / \mathrm{kg}$ boluses every $15 \mathrm{~min}$, beginning $60 \mathrm{~min}$ after the initial administration of endotoxin. Diluent was administered in an analogous fashion. The animals were observed for $3 \mathrm{~h}$ and were then killed under deep anesthesia. At the time of killing ( $180 \mathrm{~min})$, the liver, spleen, and heart were removed, washed three times in chilled PBS $\left(4^{\circ} \mathrm{C}\right)$, and frozen in liquid nitrogen. Total RNA and cytosolic proteins were prepared as described earlier.

Detection of TNF $\alpha$ mRNA in the liver, spleen, and heart from diluent- and endotoxin-treated animals was performed using PCR amplification, according to the methods described by Ma et al (36). The oligonucleotide primers were chosen based on unique cDNA sequences published for feline TNF $\alpha$ (GenBank sequence FDTNFA). The sense (S) primer (5'-CTTCTCGAACTCCGAGTGACAAGCC-3') was derived from bases $239-254$ of the coding region of TNF $\alpha$; the antisense primer (AS) used ( 5 '-TGATGGCGTGGGTGAGGAGCACATG-' 3 ) was derived from bases $445-470$ of the coding region of TNF $\alpha$. PCR amplification of total mRNA from spleen, liver, and heart was performed by denaturing the samples at $80^{\circ} \mathrm{C}$ for $5 \mathrm{~min}$ in a volume of $10 \mu \mathrm{l}$ containing $1 \times$ reverse transcriptase (RT) ${ }^{1}$ buffer (GIBCO BRL, Gaithersburg, MD), $1.0 \mu \mathrm{M}$ AS primer, and $1.0 \mathrm{mM}$ dNTP. RT was initiated by the addition of $5 \mu \mathrm{l}$ of RT mix: $1.5 \mu \mathrm{l}$ RT ( $10 \mathrm{U} / \mu \mathrm{l}$; Promega Corp., Madison, WI), $1.5 \mu \mathrm{l}$ RNAsin (40 U/ $\mu \mathrm{l}$; Promega), $1.5 \mu \mathrm{l}$ 0.1 M DTT, $0.5 \mu \mathrm{l} 10 \times \mathrm{RT}$ buffer at $37^{\circ} \mathrm{C}$ for $60 \mathrm{~min}$. To control for the possibility that the resulting PCR product was secondary to DNA contamination, the mRNA samples from spleen, liver, and heart were incubated in the above reaction mixture without added $\mathrm{RT}$.

PCR amplification was performed by adding $16 \mu$ l of a PCR mix to $4 \mu \mathrm{l}$ of cDNA product, which resulted in $1 \times$ PCR buffer, $0.2 \mathrm{mM}$

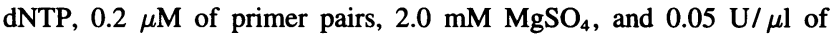
Taq polymerase. The parameters for PCR amplification were exactly as described previously (36) and were carried out for 30 cycles. The PCR reaction products were separated on $1.5 \%$ agarose gel, stained with ethidium bromide, and visualized by ultraviolet light.

TNF $\alpha$ proteins in the spleen, liver, and hearts of diluent- and endotoxin-treated animals were assayed using a modification of the method

1. Abbreviation used in this paper: RT, reverse transcription. 
of Pizarro et al. (31), as described earlier. TNF $\alpha$ bioactivity was determined using the L929 cytotoxicity assay, as described later. The amount of TNF $\alpha$ bioactivity per sample was normalized by the total amount of cytosolic protein. In addition, we performed in situ hybridization studies on the hearts obtained from animals stimulated in vivo either with endotoxin or diluent $(180 \mathrm{~min})$, to determine the cellular source for TNF $\alpha$ production.

\section{Biological activity of myocardial TNF $\alpha$}

$T N F \alpha$-induced cytotoxicity. The methods for assessing TNF $\alpha$-induced cytotoxicity have been described previously (37) and were adhered to strictly, except that we used actinomycin D $(1 \mu \mathrm{g} / \mathrm{ml})$-treated L929 cells as the TNF $\alpha$-sensitive reporter cell line, as opposed to 1591-RE 3.5 cells. Cytotoxicity was determined at $24 \mathrm{~h}$ using a colorimetric 3-[ 4,5-dimethylthiazol-s-yl]-2,5-diphenyltetrazolium bromide (MTT) assay, as described (37). All values were reported as the mean of triplicate measurements. The specificity of all TNF $\alpha$-induced effects was determined by neutralization of serum/cytosolic cytotoxicity with an anti-TNF $\alpha$ antibody (Genzyme Corp.) (37). In preliminary control experiments, we determined that the lower limit of sensitivity for this technique was in the range of 2-4 U/ml of TNF $\alpha$ and that each interand intra-assay coefficient of variation for this bioassay was $<5.0 \%$; these values are similar to those we reported for 1591-RE 3.5 cells (37).

$T N F \alpha$-induced negative inotropic effects. The presence or absence of TNF $\alpha$ in the superfusates of the diluent- and endotoxin-treated hearts was also assessed using a simple cell motion assay, exactly as described previously $(13,37)$. Briefly, adult feline cardiac myocytes were freshly isolated $(24,25,30)$, allowed to stabilize for $1 \mathrm{~h}$, and then treated for $30 \mathrm{~min}$ at $37^{\circ} \mathrm{C}$ with a $1: 5$ or $1: 10$ dilution of superfusate from either diluent- or endotoxin-treated hearts. The appropriate controls for these studies consisted of myocytes treated with diluent alone (1\% HSA) or $200 \mathrm{U} / \mathrm{ml}$ recombinant human TNF $\alpha$ (thTNF $\alpha$ ) (Genzyme Corp.). To confirm the specificity of any superfusate-induced effects on cell motion, the 1:5 dilution of the superfusate from the endotoxin-treated heart was preincubated for $60 \mathrm{~min}$ with $1.0 \mu \mathrm{l} / \mathrm{ml}$ of a neutralizing polyclonal rabbit anti-human TNF $\alpha$, as we described previously (13). Cell motion was characterized by video-edge detection, at a stimulation frequency of $0.25 \mathrm{~Hz}$, using experimental conditions identical to those we described elsewhere $(13,37)$. For these studies, we examined the percentage of change in cell length. To compare results between different myocyte isolations, the values for cell shortening were expressed as a fold-change in the amplitude of cell shortening compared with control values from that same myocyte isolation. Thus, for each of the dose-response studies described earlier, there was always an appropriate control group that was obtained from the same primary myocyte isolation.

\section{Statistics}

Each value is expressed as a mean \pm SE. Nonpaired Student's $t$ test was used to examine TNF $\alpha$ levels in diluent and endotoxin treated hearts in vitro and in vivo. One-way analysis of variance was used to test for mean differences in cell shortening after treatment with rhTNF $\alpha$ or to test for superfusates from the endotoxin- or diluent-treated hearts; where appropriate, post-hoc multiple comparison testing (Dunnett's test) was performed to test for differences between control and experimental groups. Significant differences were said to exist at $P<0.05$.

\section{Results}

Myocardial TNFa protein production in vitro. Fig. 1 illustrates the time course for the appearance of TNF $\alpha$ bioactivity in the superfusate from a typical freshly isolated, buffer-perfused heart stimulated with endotoxin $(125 \mu \mathrm{g} / \mathrm{ml})$. As shown, TNF $\alpha$ bioactivity was not detectable in the myocardial superfusate under baseline conditions; however, TNF $\alpha$ bioactivity was detectable in the superfusate $90 \mathrm{~min}$ after endotoxin administration and continued to increase throughout the course of endotoxin stimulation (total $180 \mathrm{~min}$ ). TNF $\alpha$ bioactivity in the superfusate from

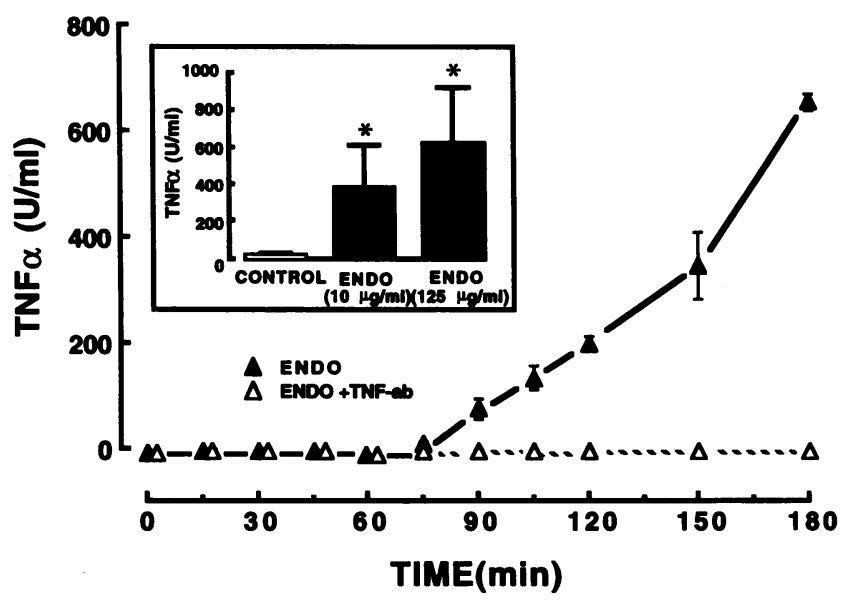

Figure 1. Myocardial TNF $\alpha$ production in vitro. Freshly excised cat hearts were perfused for 180 min with diluent, 10 or $125 \mu \mathrm{g} / \mathrm{ml}$ of endotoxin. TNF $\alpha$ bioactivity (L929 cytotoxicity assay; mean \pm SEM of measurements performed in triplicate) was assessed in the myocardial superfusates starting immediately after endotoxin stimulation (time 0 ). The large panel shows the time course of appearance of TNF $\alpha$ bioactivity (closed triangles) for a representative heart treated with endotoxin $(125 \mu \mathrm{g} / \mathrm{ml})$; TNF $\alpha$ bioactivity was completely neutralized at each time point by an anti-TNF $\alpha$ antibody (open triangles). The inset of this figure depicts the values obtained for group data for hearts perfused (180 $\mathrm{min}$ ) with diluent (open bar; $n=5$ hearts), $10 \mu \mathrm{g} / \mathrm{ml}$ endotoxin (solid bar; $n=5$ hearts), or $125 \mu \mathrm{g} / \mathrm{ml}$ endotoxin (solid bar; $n=3$ hearts). $E N D O$, endotoxin; $* P<0.05$ compared with diluent-treated hearts.

the endotoxin-stimulated heart was completely neutralized, at each of the time points tested, by pretreating the superfusate with a polyclonal antibody directed against TNF $\alpha$ (37). The inset shown in Fig. 1 depicts group data for feline hearts perfused (180 min) with diluent $(n=5), 10 \mu \mathrm{g} / \mathrm{ml}$ endotoxin ( $n$ $=5$ ), or $125 \mu \mathrm{g} / \mathrm{ml}$ endotoxin $(n=3)$. The salient finding shown by this inset is that, whereas TNF $\alpha$ bioactivity was not detected in any of the diluent-treated hearts, TNF $\alpha$ bioactivity was significantly increased in the superfusates from the hearts stimulated with either 10 or $125 \mu \mathrm{g} / \mathrm{ml}$ of endotoxin $(P<0.01$ and $<0.001$, respectively, compared with control values). The specificity of the TNF $\alpha$-induced cytotoxic effects was confirmed using an anti-TNF $\alpha$ antibody, which neutralized the cytotoxicity in the superfusates obtained with either 10 or 125 $\mu \mathrm{g} / \mathrm{ml}$ of endotoxin.

Myocardial TNF $\alpha$ mRNA production in vitro. Fig. $2 A$ shows that TNF $\alpha$ mRNA was not detectable by Northern blot analysis at baseline or any of the other time points examined in the heart stimulated with diluent alone. In striking contrast, Fig. $2 B$ shows that TNF $\alpha$ mRNA was expressed as early as 30 min after endotoxin provocation and did not increase further between 60 and $90 \mathrm{~min}$. Similar qualitative findings with respect to TNF $\alpha$ mRNA expression were observed in two additional hearts stimulated with endotoxin. Fig. $2 C$ shows that once TNF $\alpha$ mRNA was expressed, the mRNA levels were dynamic and directly related to the presence or absence of endotoxin in the superfusate. That is, when hearts were stimulated with endotoxin for $90 \mathrm{~min}$ and then perfused for an additional $120 \mathrm{~min}$ with buffer without supplemental endotoxin, TNF $\alpha$ mRNA levels decreased rapidly toward baseline levels within $210 \mathrm{~min}$, whereas in comparable experimental preparations treated continuously with en- 

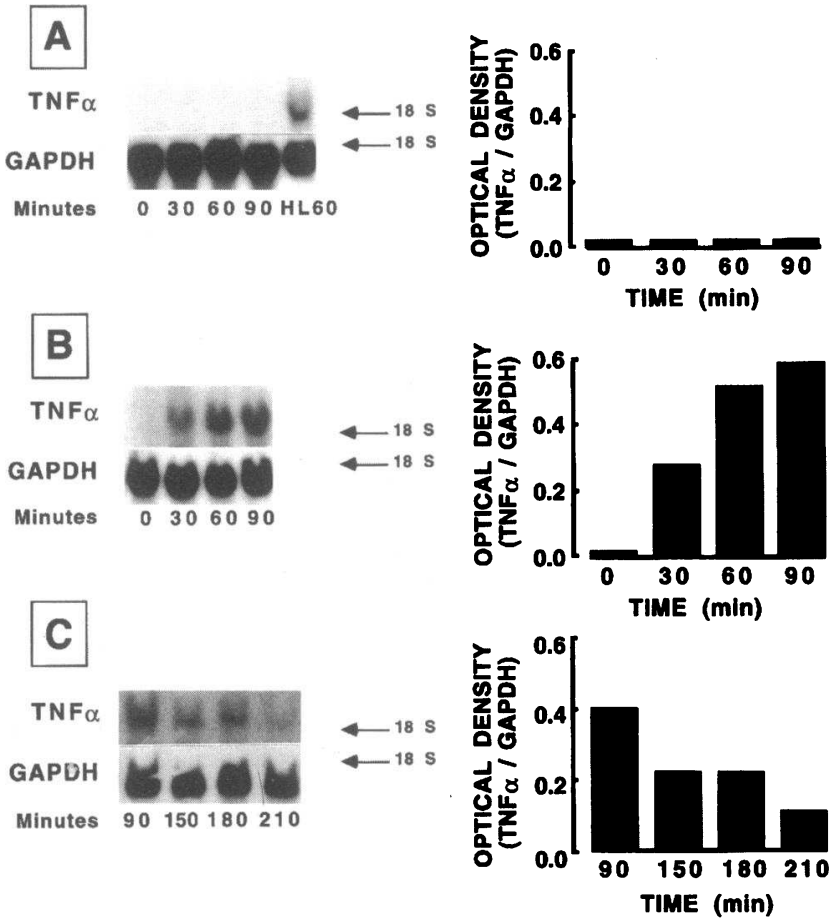

Figure 2. Myocardial TNF $\alpha$ gene expression in vitro. TNF $\alpha$ gene expression was assessed by Northern blot analysis in freshly isolated hearts perfused for various times with diluent or endotoxin $(125 \mu \mathrm{g} / \mathrm{ml})$; the expression of GAPDH mRNA was used as an internal control. $A$ shows the Northern blot analysis for TNF $\alpha$ mRNA levels after diluent administration (0-180 min); mRNA isolated from endotoxin-stimulated (125 $\mu \mathrm{g} / \mathrm{ml}$ for $180 \mathrm{~min}$ ) HLA60 cells was used as positive control and was processed along with the mRNA from the diluent-stimulated hearts under identical conditions. $B$ shows the time course for the appearance of TNF $\alpha$ mRNA after administration of endotoxin; $C$ shows the time course for the decrease in TNF $\alpha$ mRNA levels after 90 min of stimulation with endotoxin ( $125 \mu \mathrm{g} / \mathrm{ml}$ ). The graphs accompanying $A-C$ show the relative optical density of the hybridization signal for TNF $\alpha$, normalized to the hybridization signal for GAPDH.

dotoxin for $210 \mathrm{~min}$, TNF $\alpha$ mRNA levels were constant (data not shown). Similar qualitative findings with respect to TNF $\alpha$ mRNA expression after the removal of endotoxin were observed in two additional hearts.

Intramyocardial immunolocalization of TNF $\alpha$. Fig. 3 summarizes the results of the immunohistochemical studies conducted to visualize the presence and anatomic localization of TNF $\alpha$ within the myocardium. Fig. $3 A$ shows that TNF $\alpha$ immunostaining was not detected in the hearts perfused with diluent alone. In striking contrast to the findings in diluent-stimulated hearts, Fig. 3, $C$ and $D$, demonstrates that there was obvious TNF $\alpha$ immunostaining in the endotoxin-stimulated hearts. TNF $\alpha$ immunostaining was localized to a variety of cell types, including endothelial cells and smooth muscle cells in the blood vessels and, perhaps most surprising, to the cardiac myocytes themselves. Fig. $3 B$ shows that there was no nonspecific myocardial immunostaining for TNF $\alpha$ when endotoxin-stimulated hearts were incubated with secondary antibody alone. Similar qualitative findings were observed with additional endotoxin ( $n$ $=2)$ and diluent $(n=2)$ stimulated hearts.

Cellular source for myocardial TNF $\alpha$ production. The presence of TNF $\alpha$ immunostaining on the cardiac myocytes sug- gested one of two possibilities: TNF $\alpha$ produced by nonmyocytes became bound to, and therefore immunolocalized to, TNF receptors on the cardiac myocytes (32); alternatively, precursor TNF $\alpha$ (26-kD) was synthesized by the cardiac myocyte and bound to the sarcolemma (38). To explore the latter possibility, we performed a series of three interrelated experiments to determine whether the cardiac myocyte might be a source for TNF $\alpha$ production.

Fig. 4 compares and contrasts the relative production of TNF $\alpha$ mRNA and protein by cardiac myocytes and nonmyocyte cell types in the heart after endotoxin stimulation $(n=3)$. As shown in the top of Fig. 4, the supernatants from the cell isolation predominately composed of nonmyocyte cell types ( $>$ 95\%) expressed both TNF $\alpha$ mRNA and protein. The bottom of Fig. 4 shows that the cell pellets predominantly composed of cardiac myocytes ( $>95 \%$ ) expressed both TNF $\alpha$ mRNA and protein, although the relative amount of TNF $\alpha$ mRNA in the cell pellet appeared less when compared with that observed in the cell supernatants.

To define more definitively the presence of TNF $\alpha$ mRNA in cardiac myocytes, we performed in situ hybridization studies in diluent- and endotoxin-stimulated hearts. Fig. 5, $A$ and $B$, which serves as the appropriate positive control for the in situ hybridization studies, shows that there was obvious cytoplasmic and nuclear labeling of the cardiac myocytes in the diluent $(A)$ and endotoxin- $(B)$ stimulated hearts when poly $\mathrm{T}$ oligonucleotide probes were used. Fig. $5, C$ and $D$, shows that when the diluent- and endotoxin-stimulated hearts were hybridized with the antisense TNF $\alpha$ oligonucleotide probe, there was no labeling of the cardiac myocytes in the diluent-treated hearts $(C)$, whereas there was obvious nuclear and cytoplasmic labeling of the cardiac myocytes in the endotoxin-stimulated hearts $(D)$. Finally, as shown in Fig. 5, $E$ and $F$, the sense TNF $\alpha$ oligonucleotide probe did not hybridize to any cell types in the diluent- $(E)$ or endotoxin-stimulated hearts $(F)$. Similar qualitative findings were obtained when the antisense and sense probes were used in additional in situ hybridization studies in endotoxin- $(n=2)$ and diluent- $(n=2)$ stimulated hearts.

Third, to determine whether endotoxin challenge would directly stimulate the production of TNF $\alpha$ protein in cultured cardiac myocytes, freshly isolated feline myocytes were stimulated with either diluent ( $n=6$ primary myocyte isolations) or $10 \mu \mathrm{g} / \mathrm{ml}$ endotoxin ( $n=6$ primary myocyte isolations). This study showed that TNF $\alpha$ bioactivity was at the lower limit of detectability in the diluent-treated cultures $(19 \pm 19$ U TNF $\alpha$ / gram of cell protein), whereas the level of TNF $\alpha$ bioactivity was significantly higher $(P<0.001)$ in the endotoxin-treated cultures $(998 \pm 630 \mathrm{U} / \mathrm{ml} \mathrm{TNF} \alpha /$ gram of cell protein $)$.

Three control experiments were performed to determine the degree to which monocyte contamination may have contributed to the TNF $\alpha$ bioactivity observed in the endotoxin-stimulated myocyte cultures. First, based on identification by either membrane expression of CD14 or by phagocytosis of fluorescent beads, the percentage of contaminating monocytes in the cardiac myocyte cultures was estimated at $0.4-0.7 \%$. Thus, a culture of $1 \times 10^{6}$ cardiac myocytes would contain $<1 \times 10^{4}$ monocytes. However, when cultures of $1 \times 10^{5}$ mononuclear leukocytes (containing $\sim 1 \times 10^{4}$ monocytes) were stimulated with endotoxin, TNF $\alpha$ bioactivity was undetectable. Moreover, it was not until the number of cultured of mononuclear leukocytes was increased 50-fold that we were able to detect TNF $\alpha$ bioactivity similar to that produced by $1 \times 10^{6}$ cardiac myocytes. Lastly, 


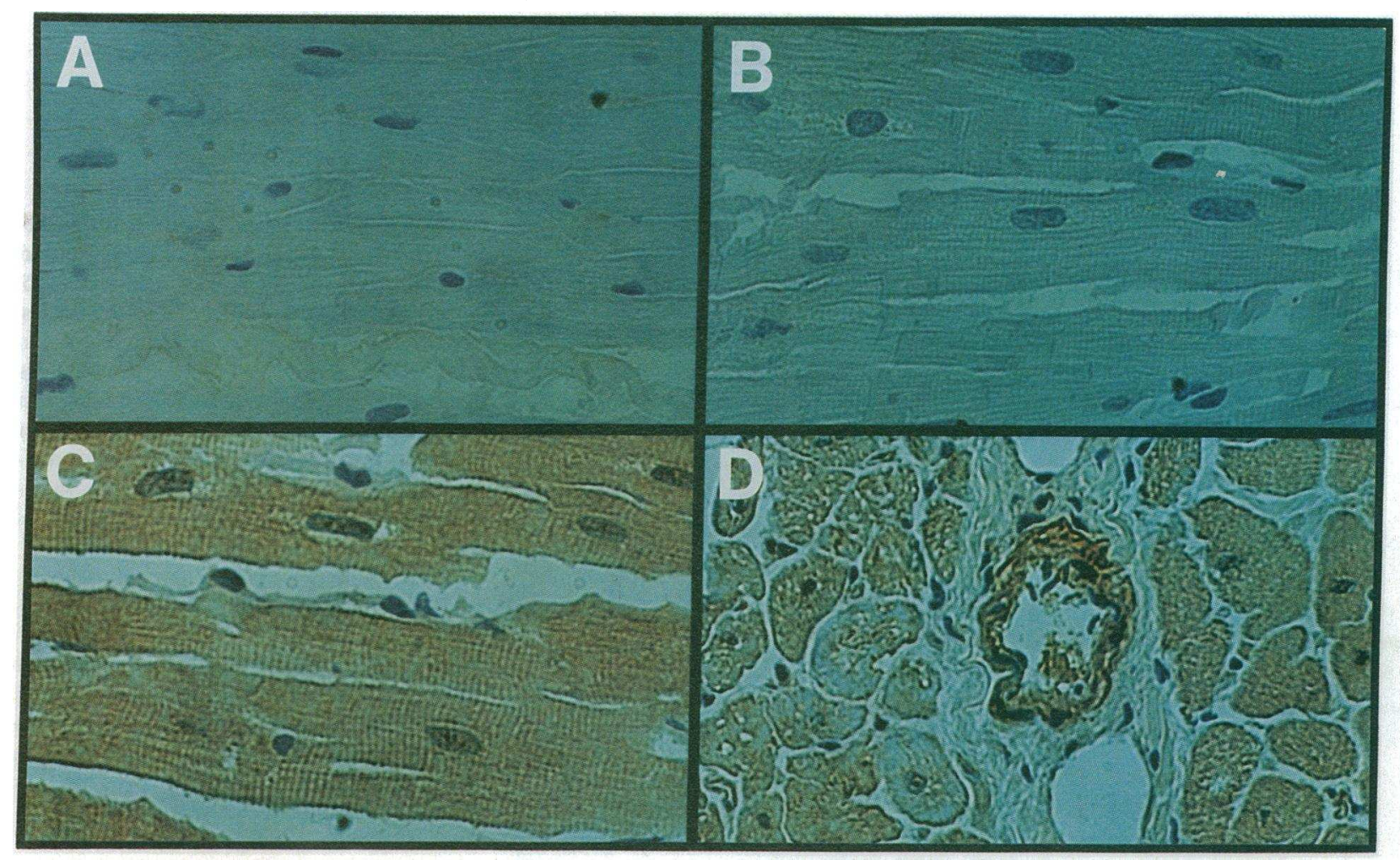

Figure 3. Immunolocalization of myocardial TNF $\alpha$ in vitro. Immunohistochemical studies were performed in freshly excised feline hearts stimulated for $180 \mathrm{~min}$ with diluent or endotoxin $(125 \mu \mathrm{g} / \mathrm{ml})$, and the hearts were fixed and sectioned using standard methodology. Myocardial samples from diluent- and endotoxin-stimulated hearts were incubated with a primary antibody directed against human TNF $\alpha$ and a biotin conjugated goat antirabbit secondary antibody. All slides were developed using a peroxidase reporter (see text for details) and were counterstained with hematoxylin. $A$ shows the immunostaining pattern obtained in a diluent-stimulated heart using both primary and secondary antibodies; $B$ shows the immunostaining pattern obtained in an endotoxin-stimulated heart using a secondary antibody alone (negative control); $C$ and $D$ show the immunostaining pattern in a representative endotoxin-stimulated heart using both primary and secondary antibodies. All photographs were obtained at $\times 400$.

the quantity of TNF $\alpha$ production in the endotoxin-treated cardiac myocyte cultures depleted of monocytes $(776.4 \pm 511 \mathrm{U} /$ gram; $n=4$ dishes $)$ was not significantly different $(P>0.05)$ when compared with myocyte cultures containing $0.4-0.7 \%$ contaminating monocytes $(853.9 \pm 537 \mathrm{U} /$ gram; $n=4$ dishes $)$.

Functional significance of myocardial TNF $\alpha$ production.
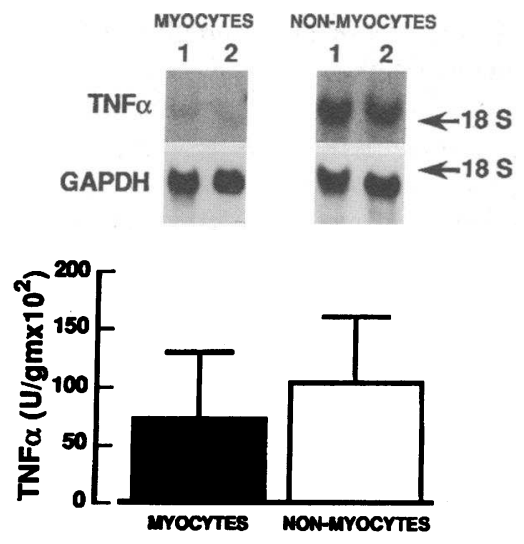

nonmyocytes) were split into two portions an mRNA and protein synthesis, as described in Methods. Top and bottom show, respectively, the TNF $\alpha$ mRNA and protein levels in nonmyocyte and myocyte fractions obtained from endotoxin-stimulated hearts.
To determine whether the TNF $\alpha$ produced by the endotoxinstimulated hearts was sufficient to modulate contractility of cardiac myocytes, we incubated freshly isolated cardiac myocytes for $30 \mathrm{~min}$ with superfusates from diluent- and endotoxintreated hearts. As shown in Fig. 6, when the isolated cardiac myocytes were incubated with a 1:5 dilution of the superfusate from the diluent-treated hearts, cell motion was not affected. However, when the cells were incubated with a 1:5 dilution of the superfusate from the endotoxin-treated heart $(\sim 200 \mathrm{U} / \mathrm{ml}$ TNF $\alpha$ ), there was an $\sim 25 \%$ decrease in the extent of cell shortening, similar to the decrease in cell shortening observed when recombinant human TNF $\alpha(200 \mathrm{U} / \mathrm{ml})$ was used. Moreover, the negative inotropic effects of the superfusate from the endotoxin-treated hearts could be completely abrogated by pretreatment with a neutralizing polyclonal TNF $\alpha$ antibody. Analysis of variance indicated that the overall differences in cell shortening among groups were significant $(P<0.001)$; posthoc analysis of variance testing (Dunnett's test) indicated that the decrease in the extent of cell shortening for cells treated with the 1:5 dilution of the superfusate from the endotoxintreated hearts or recombinant human TNF $\alpha$ was significantly different from control $(P<0.05)$, whereas the extent of cell shortening for the cells treated with superfusate from the diluent-treated hearts or the superfusate pretreated with a neutralizing polyclonal antibody was not significantly different from control $(P>0.05)$. 


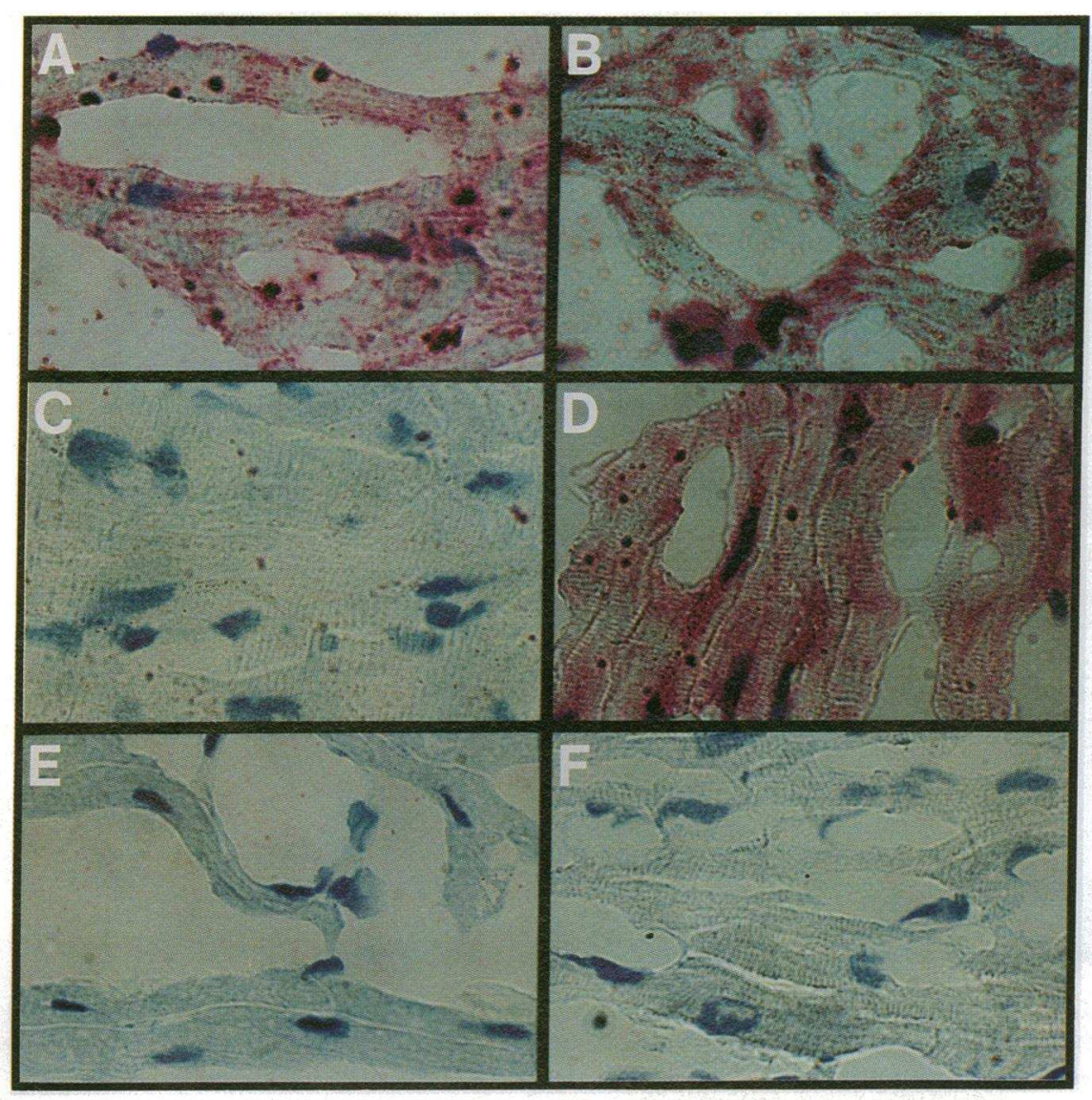

Figure 5. In situ hybridization studies in diluentand endotoxin-stimulated hearts. Freshly isolated cat hearts were stimulated with endotoxin ( 125 $\mu \mathrm{g} / \mathrm{ml}$ ) or diluent for $180 \mathrm{~min}$; then the tissues were fixed and prepared for in situ hybridization using specific biotinylated probes (see Methods for details). All slides were developed using Fast Red chromagen solution. The left-hand column shows the in situ hybridization studies for diluent-treated hearts; the right-hand column shows the results for endotoxin-stimulated hearts. $A$ and $B$ (positive controls) show that when a poly $\mathrm{T}$ oligonucleotide probe was used there was obvious cytoplasmic and nuclear labeling of the cardiac myocytes in both the diluent- and endotoxin-stimulated hearts. $C$ and $D$ show that when the diluent- and endotoxin-stimulated hearts were hybridized to the TNF $\alpha$ antisense oligonucleotide there was obvious labeling of the cytoplasm and nucleus of the cardiac myocytes from the endotoxin-stimulated hearts, whereas there was no hybridization signal evident in the nucleus or cytoplasm of the myocytes in the diluent-treated hearts. $E$ and $F$ show that the TNFa sense probe did not hybridize to any cell types in the diluent- or endotoxin-stimulated hearts.
Myocardial TNF $\alpha$ mRA and protein biosynthesis in vivo. To determine whether the systemic administration of endotoxin in vivo leads to the compartmentalized production of TNF $\alpha$ mRNA and protein production in the heart, as suggested by the in vitro studies, we challenged cats with either endotoxin or diluent. To determine whether compartmentalized production of TNF $\alpha$ was unique to the heart or whether instead TNF $\alpha$ was produced in other organ systems as well, we also examined TNF $\alpha$ mRNA and protein production in the liver and spleen. The top of Fig. 7 depicts the mRNA levels for heart, liver, and spleen in diluent- $(A)$ and endotoxin- $(B)$ treated heart. As shown, TNF $\alpha$ mRNA was barely detectable by PCR in the liver (lane 2) and spleen (lane 3) and was not detectable in the heart (lane 1) after diluent administration. In contrast, TNF $\alpha$ mRNA was easily detectable by PCR in the heart (lane 1), liver (lane 2 ), and spleen (lane 3) after administration of endotoxin. TNF $\alpha$ PCR product was not detectable in the heart, liver, or spleen of diluent- or endotoxin-stimulated hearts in the absence of RT (lanes 4-6), thereby excluding the presence of DNA contamination. The bottom of Fig. 7 shows that TNF $\alpha$ bioactivity was detectable in the cytosolic fractions obtained from the liver and spleen of animals treated with diluent alone, whereas TNF $\alpha$ was not evident in the heart $(A)$. In contrast, TNF $\alpha$ bioactivity was readily detectable in the cytosolic fractions of the heart, liver, and spleen obtained from endotoxin-stimulated animals (Fig. 7 B). In each instance, TNF $\alpha$ bioactivity in the cytosolic fractions from the organs obtained from both diluent- and endotoxin-stimulated animals could be completely neutralized by a polyclonal anti-TNF $\alpha$ antibody.
To determine the cellular source(s) of TNF $\alpha$ mRNA production in the earlier in vivo studies, we performed in situ hybridization studies in hearts from the diluent- and endotoxinstimulated cats. Fig. 8, $A$ and $B$, shows, respectively, that when an antisense TNF $\alpha$ oligonucleotide probe was hybridized to myocardium obtained from diluent- and endotoxin-stimulated animals, the probe did not hybridize to any of the myocardial cells from the animal stimulated with diluent $(A)$, whereas there was obvious cytoplasmic labeling in the cardiac myocytes from the endotoxin-stimulated animal $(B)$. Fig. 8, $C$ and $D$, shows, respectively, that the sense TNF $\alpha$ oligonucleotide probe did not hybridize to any cell types in the myocardial samples from the diluent- or endotoxin-stimulated cats.

\section{Discussion}

This simple experimental study, in which the effects of endotoxin were systematically studied in the heart in vitro and in vivo, shows that the adult mammalian heart efficiently synthesizes biologically active TNF $\alpha$. Five distinct but mutually complementary lines of evidence support this statement. First, whereas TNF $\alpha$ bioactivity was not detectable in the myocardial superfusates (Fig. 1, inset) from the freshly isolated bufferperfused hearts stimulated with diluent, there was a striking increase in the elaboration of biologically active TNF $\alpha$ in the superfusates from the endotoxin-stimulated hearts (Fig. 1, and inset). TNF $\alpha$ bioactivity, which was evident as early as $90 \mathrm{~min}$ after endotoxin stimulation, continued to increase throughout the course of endotoxin stimulation. Second, whereas TNF $\alpha$ 


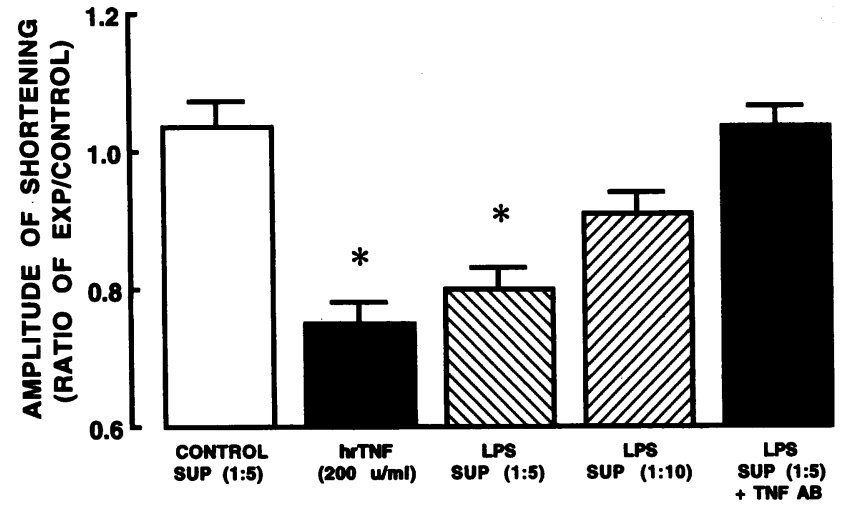

Figure 6. Functional significance of myocardial TNF $\alpha$ biosynthesis. Freshly isolated cardiac myocytes were incubated for $30 \mathrm{~min}$ with superfusates from diluent- and endotoxin- $(125 \mu \mathrm{g} / \mathrm{ml})$ stimulated hearts, and the extent of cell shortening was determined using video-edge detection ( see Methods for details). The extent of cell shortening is expressed as a fold change in cell length compared with values in cells studied in KHB buffer alone. The open bar depicts the fold-change in cell length for cells $(n=9$ cells) treated with superfusates from diluent-stimulated hearts; the solid bar depicts the values for cell shortening for cells ( $n$ $=12$ cells $)$ treated with $\operatorname{thTNF} \alpha(200 \mathrm{U} / \mathrm{ml})$; the hatched bars depict the values for cell shortening for cells treated with a 1:5 $(n=13$ cells $)$ or a 1:10 ( $n=14$ cells) dilution of the superfusates from endotoxintreated hearts; the shaded bar ( $n=17$ cells) shows the values for cell shortening for cells treated with a 1:5 dilution of the superfusate from an endotoxin-treated heart neutralized previously with a polyclonal antiTNF $\alpha$ antibody. The absolute value for cell shortening for cells whose motion was studied in KHB alone was $11.13 \pm 0.43 \%$, which is similar to values we have reported previously $(13,37) .{ }^{*} P<0.05$ relative to control values.

mRNA was not detectable in naive (unstimulated) hearts (Fig. $2 A)$, TNF $\alpha$ mRNA was expressed rapidly $(30 \mathrm{~min}$ ) in the myocardium after endotoxin administration (Fig. $2 B$ ). Although the coordinated expression of TNF $\alpha$ mRNA and protein in the heart argues for a transcriptional control mechanism for cytokine biosynthesis, the presence of an AT-rich region in the $3^{\prime}$ untranslated region of the TNF $\alpha$ gene suggests an alternative mechanism. That is, these sequences (TTATTTAT; reference 39 ), which are common in the $3^{\prime}$ untranslated regions of a variety of inflammatory cytokines, have been shown to promote mRNA instability $(39,40)$. Accordingly, we cannot discount the possibility that TNF $\alpha$ biosynthesis may have occurred, either wholly or in part, as a result of posttranscriptional stabilization of TNF $\alpha$ mRNA levels. Germane to this discussion was the finding that TNF $\alpha$ mRNA levels returned rapidly toward baseline levels once endotoxin was removed from the superfusate (Fig. $2 C$ ), thus suggesting that TNF $\alpha$ gene expression was tightly regulated in the heart. Third, immunohistochemical staining studies localized TNF $\alpha$ to cardiac myocytes as well as to endothelial cells, smooth muscle cells in the hearts stimulated with endotoxin, whereas TNF $\alpha$ immunostaining was not apparent in the diluent-stimulated hearts (Fig. 3). Fourth, when isolated cardiac myocytes were exposed to the superfusates (1:5 dilution) from the endotoxin-stimulated hearts, cell motion was depressed to a degree similar to that observed with recombinant human TNF $\alpha$ (Fig. 6); superfusates from diluent-treated hearts had no effect on cell motion. Moreover, the negative inotropic effect of the superfusates from the endotoxin-stimulated hearts could be abrogated completely by pretreating the superfusates
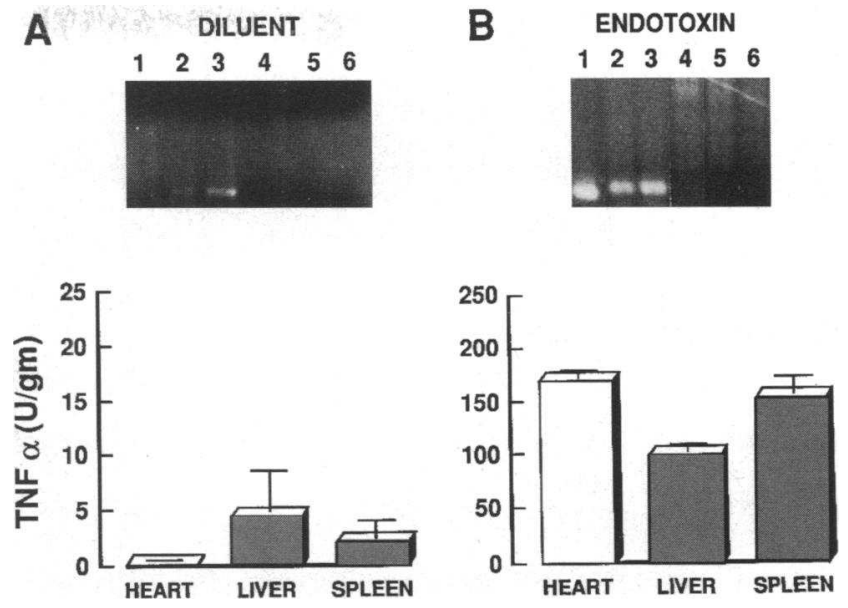

Figure 7. Myocardial TNF $\alpha$ mRNA and protein biosynthesis in vivo. Myocardial TNF $\alpha$ gene and protein biosynthesis were examined in vivo in cats stimulated with endotoxin or TNF $\alpha$. $A$ and $B$ summarize the findings with respect to TNF $\alpha$ mRNA and protein synthesis in the heart, liver, and spleen from animals treated with diluent or endotoxin, respectively. The upper portion of each panel shows the RT $(+)$ PCR products for TNF $\alpha$ mRNA from heart (lane 1), liver (lane 2), and spleen (lane 3 ) and the corresponding RT (-) PCR products (negative controls) for heart (lane 4), liver (lane 5), and spleen (lane 6). The lower portion of each panel shows the TNF $\alpha$ protein levels in the cytosolic fractions from the heart, liver, and spleen from diluent- and endotoxin-treated animals. Peripheral circulating levels of serum TNF $\alpha$ levels at the time of terminal killing ( $180 \mathrm{~min}$ ) were below the limits of detection after diluent treatment and were $119.7 \pm 10.8 \mathrm{U} / \mathrm{ml}$ after treatment with endotoxin.

with a neutralizing anti-TNF $\alpha$ antibody. Finally, to confirm the biological relevance of the in vitro studies presented herein, we also examined the biosynthetic effects of endotoxin in vivo. These latter studies confirmed our in vitro findings in that we again observed de novo expression of intramyocardial TNF $\alpha$ mRNA and protein synthesis in the endotoxin-stimulated animals, whereas intramyocardial TNF $\alpha$ mRNA and protein synthesis were not observed after administration of diluent in vivo (Figs. 7 and 8 ). Thus, these studies constitute the initial demonstration that the production of biologically active TNF $\alpha$ is compartmentalized within adult mammalian heart after administration of endotoxin.

A second important finding of this study was the observation that the adult cardiac myocyte synthesizes not only TNF $\alpha$ mRNA but also TNF $\alpha$ protein. Based on our immunohistochemical studies, which clearly localized TNF $\alpha$ to the cardiac myocyte, as well as previous studies that suggested that cultured cells from whole heart homogenates of newborn rat and murine hearts produced TNF $\alpha$ when stimulated with endotoxin (20, 41 ), and a recent study that suggested that myocytes isolated from burn-shocked guinea pigs elaborated TNF $\alpha$ (42), we sought to determine whether the adult cardiac myocyte might be a potential source for TNF $\alpha$ production. As shown by the in situ hybridization studies (Figs. 5 and 8 ), when a highly specific oligonucleotide probe for feline TNF $\alpha$ mRNA was used, TNF $\alpha$ mRNA was identified in the cardiac myocytes from the endotoxin-stimulated hearts, whereas TNF $\alpha$ mRNA was not detected in the myocytes from diluent-treated hearts. To determine whether the TNF $\alpha$ mRNA expressed in adult cardiac myocytes was translated into biologically active protein, we 


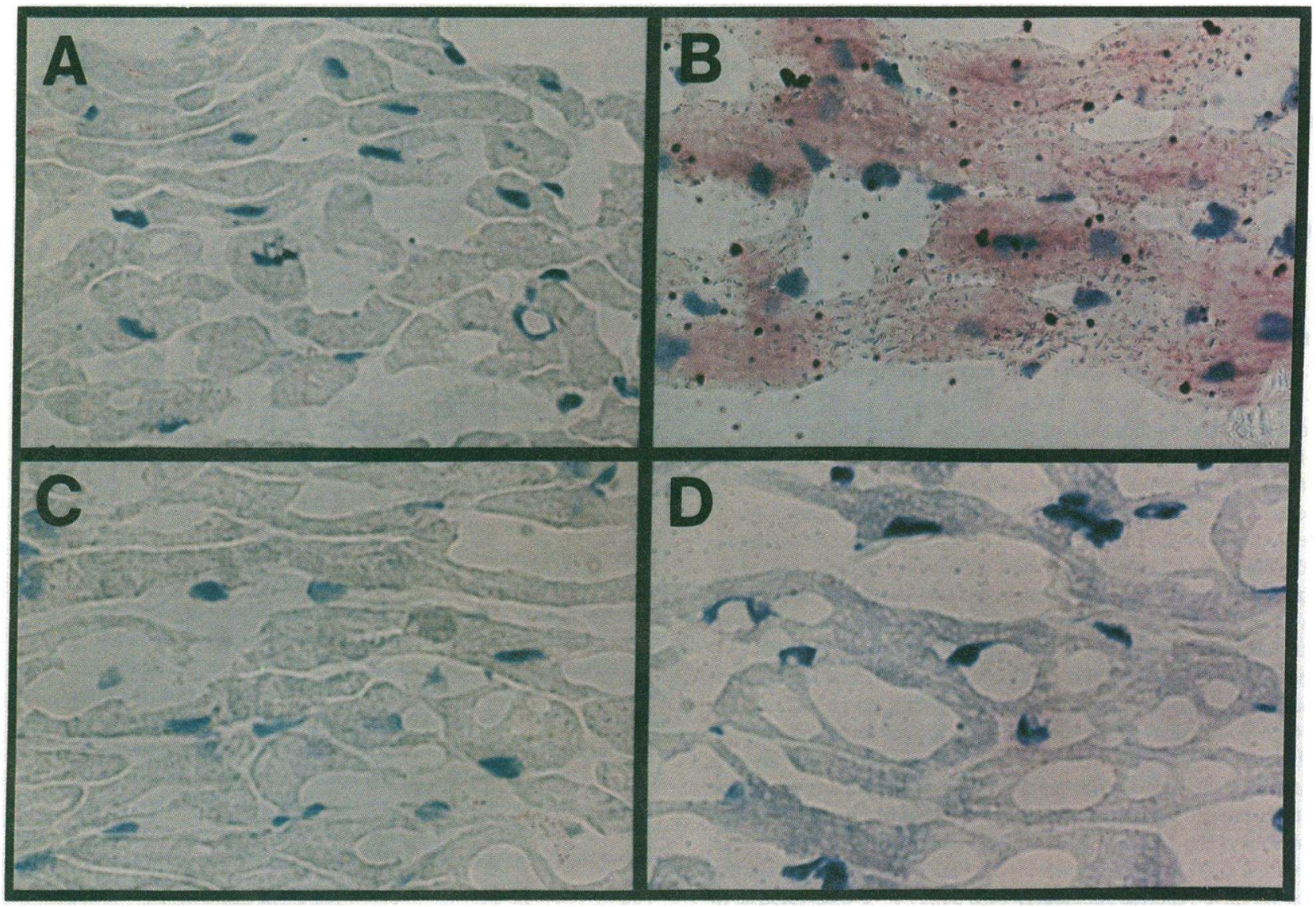

Figure 8. In situ hybridization studies in diluent- and endotoxin-stimulated cats. Cats were lightly sedated and stimulated for 180 min with either diluent or endotoxin $(100 \mu \mathrm{g} / \mathrm{kg})$. The animals were killed, and the hearts were removed rapidly and prepared for in situ hybridization and immunohistochemical staining. In situ hybridization was performed on hearts obtained from the diluent- and endotoxin-stimulated animals using Fast Red chromagen solution, as described in Methods. $A$ and $B$ show, respectively, that when the hearts obtained from the diluent- and endotoxinstimulated animals were hybridized with the antisense TNF $\alpha$ oligonucleotide probe there was no labeling of the cardiac myocytes in the diluenttreated animal, whereas there was obvious labeling of the cardiac myocytes from the endotoxin-stimulated animal. $C$ and $D$ show, respectively, that the sense TNF $\alpha$ oligonucleotide probe did not hybridize to any cell type in the hearts obtained from the diluent- and endotoxin-stimulated animals.

stimulated freshly isolated adult cardiac myocytes with endotoxin. These studies showed that there was a significant increase in TNF $\alpha$ bioactivity in the endotoxin-stimulated myocyte cultures. Nonetheless, since TNF $\alpha$ mRNA levels were higher in the nonmyocyte fractions (Fig. 4), it should be recognized that the overall physiological significance of TNF $\alpha$ gene and protein expression in the cardiac myocyte is not yet clear.

Three lines of evidence suggest that it is highly unlikely that monocyte contamination was a major source for TNF $\alpha$ production in the endotoxin-stimulated myocyte cultures discussed earlier. First, we routinely use selective adhesion techniques during our myocyte isolations to minimize fibroblast contamination (43). Thus, our isolation technique would also be expected to deplete monocytes from the myocyte cultures insofar as monocytes adhere selectively to a plastic substrate, whereas adult cardiac myocytes do not. Second, myocyte cultures that were selectively depleted of monocytes before endotoxin challenge still produced TNF $\alpha$; moreover, the quantity of TNF $\alpha$ that was produced was not different from that obtained in nondepleted myocyte cultures. Third, to produce the quantity of TNF $\alpha$ that was detected in our endotoxin-stimulated cardiac myocyte preparations, we had to stimulate cultures of mononu- clear cells that contained 50 times more monocytes than the number of monocytes estimated to be contaminating our myocyte cultures.

Compartmentalized production of TNF $\alpha$. Elevated levels of TNF $\alpha$ after endotoxin administration have been well documented in humans since at least $1988(12,44)$. Whereas it is generally thought that the major source of TNF $\alpha$ production during endotoxemia is the monocyte/macrophage (12), the exact nature of the cell types involved in this process has never been established conclusively. Germane to this discussion is the recent observation that TNF $\alpha$ mRNA is expressed constitutively in a number of mammalian tissues under normal conditions (45-47) and that levels of TNF $\alpha$ mRNA are regulated differently in various tissue compartments during endotoxemia (1823 ). For example, endotoxin challenge produces no change in the constitutive levels of TNF $\alpha$ mRNA in the spleen and small bowel (18) but increases TNF $\alpha$ mRNA levels in the liver, lung, pancreas, uterus/fallopian tubes, thymus, and kidney $(18,20)$ and induces de novo TNF $\alpha$ mRNA expression in the heart (20). Further, recent experimental reports have identified positive TNF $\alpha$ immunostaining in the kidney, liver, lung, and heart after endotoxin administration (21-23), suggesting that there was 
ongoing biosynthesis of TNF $\alpha$ in these tissues. Taken together; these studies suggest that compartmentalized biosynthesis of TNF $\alpha$ within organ systems is part of a global response of the host organism to endotoxin provocation. This statement notwithstanding, the heart appears to be unique among the different tissue types studied thus far in that myocardial TNF $\alpha$ biosynthesis requires de novo gene expression.

Conclusion. This simple experimental study provides compelling evidence for the compartmentalized production of biologically active TNF $\alpha$ within the adult heart after administration of endotoxin. While direct correlations between the experimental effects of endotoxin in the isolated heart and the complex effects of endotoxemia in the heart during systemic sepsis are not appropriate, these data provide several potentially important insights into the pathogenesis of endotoxin-induced septic shock. First, the finding that endotoxin-induced production of TNF $\alpha$ is compartmentalized suggests that the depressed myocardial function that develops during systemic sepsis may be a paracrine, autocrine, or intracrine effect of TNF $\alpha$, as opposed to a systemic endocrine effect as previously supposed $(8,9)$. The significance of this statement is that TNF $\alpha$ produced within the heart and/or other tissues may not be neutralized by naturally occurring biological buffers such as circulating (shed) soluble TNF receptors (37), which by virtue of their size, charge, or tertiary structure may not penetrate the interstices of some tissues. Second, the extent of myocardial TNF $\alpha$ production per gram of tissue suggests that the heart, and undoubtedly other tissues as well, may contribute to the total cytokine burden during systemic sepsis. Indeed, the production of TNF $\alpha$ within various tissue compartments may be one of the reasons why circulating TNF $\alpha$ levels do not necessarily predict clinical outcome during systemic sepsis (48).

While these statements have focused attention on the potential deleterious effects of TNF $\alpha$ in the heart, the data also suggest an alternate hypothesis. That is, the coordinated regulation of myocardial TNF $\alpha$ mRNA and protein synthesis implies that the elaboration of TNF $\alpha$ in the heart is not a random event in nature; this in turn suggests the intriguing possibility that the biosynthesis of TNF $\alpha$ in the heart may confer some as yet unknown survival benefit to the host. While such a broad, teleological role for TNF $\alpha$ in the heart in systemic sepsis remains largely speculative at present, one can envision at least two separate portfolios of beneficial biological responses that might be induced by TNF $\alpha$ : the first set of responses would delimit the spread of microorganisms within the myocardium by upregulating the expression of cell adhesion molecules for neutrophils and monocytes as well as facilitating the generation of free radicals by these cell types $(49,50)$; the second set of responses would protect the cardiac myocyte against oxidative or hemodynamic stress by upregulating the expression of heat shock proteins or the expression of manganese superoxide dismutase, by increasing regional myocardial blood flow through the local generation of nitric oxide, and/or by protecting the cardiac myocyte against hypoxic injury (51-53). Thus, we postulate that when TNF $\alpha$ is elaborated in low concentrations in the setting of systemic sepsis, it may serve to protect the myocardium; however, when TNF $\alpha$ is elaborated in the heart at relatively higher concentrations, the protective role of TNF $\alpha$ may still occur, albeit at the expense of a profound but fully reversible $(3,13)$ depression of myocardial function.

\section{Acknowledgments}

The authors gratefully acknowledge the assistance of the following individuals: Dr. Cora Bucana for assistance with the in situ hybridization studies, Robert Geske for performing the immunohistochemical studies, Dr. Joan Hunt for critiquing the immunohistochemical studies, Jana Grana for secretarial help, and Dorellyn Lee-Jackson for technical expertise. The authors are also indebted to Dr. Andrew I. Schafer and Dr. Roger D. Rossen for their past and present support.

This work was supported by research funds from the Department of Veterans Affairs and National Institutes of Health grants P50 HL-O6H, NS 32583, and AI28071.

\section{References}

1. Pfeiffer, R. 1892. Untersuchunger uber das Cholera gift. Zeitschrift. Hyg. Infektionskran. 11:393-412.

2. Gulick, T. S., M. K. Chung, S. J. Pieper, L. G. Lange, and G. F. Schreiner. 1989. Interleukin 1 and tumor necrosis factor inhibit cardiac myocyte $\beta$-adrenergic responsiveness. Proc. Natl. Acad. Sci. USA. 86:6753-6757.

3. Finkel, M. S., C. V. Oddis, T. D. Jacob, S. C. Watkins, B. G. Hattler, and R. L. Simmons. 1992. Negative inotropic effects of cytokines on the heart mediated by nitric oxide. Science (Wash. DC). 257:387-389.

4. Tracey, K. J., Y. Fong, D. G. Hesse, K. R. Manogue, A. T. Lee, G. C. Kuo, S. F. Lowry, and A. Cerami. 1987. Anti-cachectin/ TNF monoclonal antibodies prevent septic shock during lethal bacteraemia. Nature (Lond.). 330:662-664. 5. Tracey, K. J., B. Beutler, S. F. Lowry, J. Merryweather, S. Wolpe, I. W. Milsark, R. J. Hariri, T. J. Fahey III, A. Zentella, J. D. Albert, and G. T. Shires. 1986. Shock and tissue injury induced by recombinant human cachectin. Science (Wash. DC). 234:470-474.

6. Lefer, A. M. 1970. Role of a myocardial depressant factor in the pathogenesis of circulatory shock. Fed. Proc. 29:1836-1847.

7. Parrillo, J. E., C. Burch, J. H. Shelhamer, M. M. Parker, C. Nathanson, and W. Schuette. 1985. A circulating myocardial depressant substance in humans with septic shock. Septic shock patients with a reduced ejection fraction have a circulation factor that depresses in vitro myocardial cell performance. J. Clin. Invest. 76:1539-1553.

8. Lange, L. G., and G. F. Schreiner. 1994. Immune mechanisms of cardiac disease. N. Engl. J. Med. 330:1129-1135.

9. Parrillo, J. E. 1993. Pathogenetic mechanisms of septic shock. N. Engl. J. Med. 328:1471-1477.

10. Parker, M. M., J. H. Shelhamer, S. L. Bacharach, M. V. Green, C. Natanson, T. M. Frederick, B. A. Damske, and J. E. Parrillo. 1984. Profound but reversible myocardial depression in patients with septic shock. Ann. Intern. Med. 100:483-490.

11. Hung, J., and W. Y. W. Lew. 1993. Cellular mechanisms of endotoxininduced myocardial depression in rabbits. Circ. Res. 73:125-134.

12. Michie, H. R., K. R. Manogue, D. R. Spriggs, A. Revhaug, S. O'Dwyer, C. A. Dinarello, A. Cerami, S. W. Wolff, and D. W. Wilmore. 1988. Detection of circulating tumor necrosis factor after endotoxin administration. N. Engl. J. Med. 318:1481-1486.

13. Yokoyama, T., L. Vaca, R. D. Rossen, W. Durante, P. Hazarika, and D. L. Mann. 1993. Cellular basis for the negative inotropic effects of tumor necrosis factor-alpha in the adult mammalian heart. J. Clin. Invest. 92:2303-2312.

14. de Groote, M. A., M. A. Martin, P. Densen, M. A. Pfaller, and R. P. Wenzel. 1989. Plasma tumor necrosis factor levels in patients with presumed sepsis. Results in those treated with antilipid A antibody vs placebo. JAMA 262:249-251.

15. Calandra, T., J.-D. Baumgartner, G. E. Grau, M.-M. Wu, P.-H. Lambert, J. Schellekens, J. Verhoef, and M. P. Glauser. 1990. Prognostic values of tumor necrosis factor/ cachectin, interleukin-1, interferon- $\alpha$, and interferon-gamma in the serum of patients with septic shock. J. Infect. Dis. 161:982-987.

16. Natanson, C., P. W. Eichenholz, R. L. Danner, W. Eichacker, D. Hoffman, S. M. Kuo, T. J. Banks, T. J. MacViottie, and J. E. Parrillo. 1992. Endotoxin and tumor necrosis factor challenges in dogs simulate the cardiovascular profile of human septic shock. J. Exp. Med. 169:823-832.

17. Suffredini, A. F., R. E. Fromm, M. M. Parker, M. Brenner, J. A. Kovacs, R. A. Wesley, and J. E. Parrillo. 1989. The cardiovascular response of normal humans to the administration of endotoxin. N. Engl. J. Med. 321:280-287.

18. Ulich, T. R., K. Guo, and J. del Castillo. 1989. Endotoxin-induced cytokine gene expression in vivo. Am. J. Pathol. 134:11-14.

19. Mosmann, T. 1983. Rapid colorimetric assay for cellular growth and survival: application to proliferation and cytotoxicity assays. J. Immunol. Methods. 65:55-63.

20. Giroir, B. P., J. H. Johnson, T. Brown, G. L. Allen, and B. Beutler. 1992. The tissue distribution of tumor necrosis factor biosynthesis during endotoxemia. J. Clin. Invest. 90:693-698.

21. Tanaka, N., T. Kita, K. Kasai, and T. Nagano. 1994. The immunocytochemical localization of tumor necrosis factor and leukotriene in the rat heart and lung during endotoxin shock. Virchows Arch. (A) 424:273-277.

22. Kita, T., N. Tanaka, and T. Nagano. 1993. The immunolocalization of 
tumor necrosis factor and leukotrienes in the rat kidney after treatment with lipopolysaccharide. Int. J. Exp. Pathol. 74:471-479.

23. Nagano, T., T. Kita, and N. Tanaka. 1992. The immunocytochemical localization of tumor necrosis factor and leukotriene in the rat liver after treatment with lipopolysaccharide. Int. J. Exp. Pathol. 73:675-683.

24. Mann, D. L., R. L. Kent, and G. Cooper. 1989. Load regulation of the properties of adult feline cardiocytes: growth induction by cellular deformation. Circ. Res. 64:1079-1090.

25. Mann, D. L., R. L. Kent, B. Parsons, and G. Cooper. 1992. Adrenergic effects on the biology of the adult mammalian cardiocyte. Circulation. 85:790804.

26. Schumann, R. R., S. R. Leong, G. W. Flaggs, P. W. Gray, S. D. Wright, J. C. Mathison, P. S. Tobias, and R. J. Ulvevitch. 1990. Structure and function of lipopolysaccharide binding protein. Science (Wash. DC). 249:1429-1431.

27. Maniatis, T., E. F. Fritsch, and J. Sambrook. 1989. Molecular Cloning A Laboratory Manual. Cold Spring Harbor Laboratory, Cold Spring Harbor, NY.

28. Vilcek, J., and T. H. Lee. 1991. Tumor necrosis factor: new insights into the molecular mechanisms of its multiple actions. J. Biol. Chem. 266:7313-7316.

29. Huang, E. H., C. J. Morgan, D. D. Sedmak, R. M. Ferguson, and C. G. Orosz. 1994. Alloantigenicity in human endothelial cells. Transplantation (Baltimore). 57:703-711.

30. Mann, D. L., Y. Urabe, R. L. Kent, S. Vinciguerra, and G. Cooper. 1991 Cellular versus myocardial basis for the contractile dysfunction of hypertrophied myocardium. Circ. Res. 68:402-415.

31. Pizarro, T. T., K. Malinowska, E. J. Kovacs, J. Clancy, J. A. Robinson, and L. A. Piccinini. 1993. Induction of TNF-alpha and TNF-beta gene expression in rat cardiac transplants during allograft rejection. Transplantation (Baltimore). 56:399-404.

32. Torre-Amione, G., S. Kapadia, J. Lee, R. D. Bies, R. Lebovitz, and D. L. Mann. 1995. Expression and functional significance of tumor necrosis factor receptors in human myocardium. Circulation. In press.

33. Bucana, C. D., R. Radinsky, Z. Dong, R. Sanchez, D. J. Brigati, and I. J. Fidler. 1994. A rapid colorimetric in situ mRNA hybridization technique using hyperbiotinylated oligonucleotide probes for analysis of mdrl in mouse colon carcinoma cells. J. Histochem. Cytochem. 41:499-506.

34. Iezzoni, J., J. H. Kang, C. D. Bucana, J. A. Reed, and D. J. Brigati. 1993 Rapid colorimetric detection of epidermal growth factor receptor mRNA by in situ hybridization. J. Clin. Lab. Anal. 7:247-251.

35. Ulich, T. R., K. Guo, B. Irwin, D. G. Remick, and G. N. Davatelis. 1990. Endotoxin-induced cytokine gene expression in vivo. Am. J. Pathol. 137:11731185.

36. Ma, T. S., P. A. Brink, B. Perryman, and R. Roberts. 1994. Improved quantification with validation of multiple mRNA species by polymerase chain reaction: application to human myocardial creatine kinase $\mathbf{M}$ and B. Cardiovasc. Res. 28:464-471.

37. Kapadia, S., G. Torre-Amione, T. Yokoyama, and D. L. Mann. 1995 Soluble tumor necrosis factor binding proteins modulate the negative inotropic effects of TNF- $\alpha$ in vitro. Am. J. Physiol. 37:H517-H525.

38. Kriegler, M., C. Perez, K. Defay, I. Albert, and S. D. Lu. 1988. A nove form of TNF/ cachectin is a cell surface cytotoxic transmembrane protein: ramifications for the complex physiology of TNF. Cell. 53:45-53.

39. Caput, D., B. Beutler, K. Hartog, R. Thayer, S. Brown-Shimer, and A. Cerami. 1986. Identification of a common nucleotide sequence in the 3 '-untranslated region of mRNA molecules specifying inflammatory mediators. Proc. Natl. Acad. Sci. USA. 83:1670-1674.

40. Shaw, G., and R. Kamen. 1986. A conserved AU sequence from the $3^{\prime}$ untranslated region of GM-CSF mRNA mediates selective mRNA degradation. Cell. 46:659-667.

41. Friedman, G., R. Gallily, T. Chajek-Shaul, O. Stein, E. Shiloni, J. Etienne, and Y. Stein. 1988. Lipoprotein lipase in heart cell cultures is suppressed by lipopolysaccharide: an effect mediated by production of tumor necrosis factor. Biochim. Biophys. Acta. 960:220-228.

42. Giroir, B. P., J. W. Horton, J. D. White, K. L. McIntyre, and C. Q. Lin. 1994. Inhibition of tumor necrosis factor prevents myocardial dysfunction during burn shock. Am. J. Physiol. 267:H118-H124.

43. Cooper, G., R. L. Kent, and D. L. Mann. 1989. Load induction of cardiac hypertrophy. J. Mol. Cell. Cardiol. 21 (Suppl. V):11-30.

44. Hesse, D. G., K. J. Tracey, Y. Fong, K. R. Manogue, M. A. Palladino, A. Cerami, T. Shires, and S. F. Lowry. 1988. Cytokine appearance in human endotoxemia and primate bacteremia. Surg. Gynecol. Obstet. 166:147-153.

45. Hunt, J. S., H. L. Chen, X. L. Hu, T. Y. Chen, and D. C. Morrison. 1992. Tumor necrosis factor- $\alpha$ gene expression in the tissues of normal mice. Cytokine. 4:340-346.

46. Tovey, M. G. 1989. Expression of the genes of interferons and other cytokines in normal and diseased tissues of man. Experientia. 45:526-534.

47. Tovey, M. G., J. Content, I. Gresser, J. Gugenheim, B. Blanchard, J. Guymarho, P. Poupart, M. Gigou, A. Shaw, and W. Fiers. 1988. Genes for IFN$\beta-2$ (IL-6), tumor necrosis factor, and IL-1 are expressed at high levels in the organs of normal individuals. J. Immunol. 141:3106-3110.

48. Casey, L. C., R. A. Balk, and R. C. Bone. 1993. Plasma cytokine and endotoxin levels correlate with survival in patients with the sepsis syndrome. Ann. Intern. Med. 119:771-854.

49. Youker, K., C. W. Smith, D. C. Anderson, D. Miller, L. H. Michael, R. D. Rossen, and M. L. Entman. 1992. Neutrophil adherence to isolated adult cardiac myocytes: induction by cardiac lymph collected during ischemia and reperfusion. J. Clin. Invest. 89:602-609.

50. Tsujimoto, M., S. Yokota, J. Vilcek, and G. Weissmann. 1986. Tumor necrosis factor provokes superoxide anion generation from neutrophils. Biochem. Biophys. Res. Commun. 137:1094-1100.

51. Schulz, R., E. Nava, and S. Moncada. 1992. Induction and potential biological relevance of a $\mathrm{Ca}^{2+}$-independent nitric oxide synthase in the myocardium. Br. J. Pharmacol. 105:575-580.

52. Nakano, M., A. A. Knowlton, D. Lee-Jackson, and D. L. Mann. 1994. Tumor necrosis factor- $\alpha$ protects against hypoxic injury in adult cardiac myocytes: the role of heat shock protein 70. Circulation. 90:I-467. (Abstr.)

53. Nakata, T., K. Suzuki, J. Fujii, M. Ishikawa, and N. Taniguchi. 1993. Induction and release of manganese superoxide dismutase from mitochondria of human umbilical vein endothelial cells by tumor necrosis factor-alpha and interleukin-1 alpha. Int. J. Cancer. 55:646-650. 